\title{
KELAYAKAN PERLUASAN AREAL KEBUN KELAPA SAWIT 1000 HEKTAR (PENANAMAN BARU) DI PT BIO NUSANTARA TEKNOLOGI
}

\author{
Gita Mulyasari ${ }^{1}$ \\ Elisa Wildayana² \\ M.Yamin ${ }^{2}$ \\ ${ }^{1}$ Staf Pengajar Jurusan Sosek Fak. Pertanian UNIB \\ 2 Staf Pengajar Jurusan Sosek Fak. Pertanian UNSRI
}

\begin{abstract}
The purpose of this research are 1) to analyze TBS marketing aspect in Bengkulu Province that inflence by TBS accept and Demand. 2) to analyze technical aspect of 1.000 hectare palm oil plantation enlargement. 3) to analyze financial aspect of 1.000 hectare palm oil plantation enlargement. The research in PT. Bio Nusantara Teknologi used case method and supported by literatures study. he result of this research show that TBS marketing aspect in Bengkulu Province promised enough which increases TBS production. Technical aspect show enlargement of 1.000 hectare palm oil plantation is proper to do. From financial aspect with $18 \%$ discount factor show gross B/C 1,65, NPV Rp. 18.574.764.528 and IRR 19,06\%, is proper to do.
\end{abstract}

Key Words :Feasibility study, new planting, estate,extensification

\section{PENDAHULUAN}

Kelapa sawit merupakan tumbuhan tropis yang tergolong dalam famili Palmae dan berasal dari Afrika Barat. Meskipun demikian, ada yang menyatakan bahwa kelapa sawit berasal dari Amerika Selatan yaitu Brazil karena lebih banyak ditemukan spesies kelapa sawit di hutan Brazil dibandingkan dengan Afrika. Pada kenyataannya tanaman kelapa sawit hidup subur di luar daerah asalnya, seperti Malaysia, Indonesia, Thailand, dan Papua Nugini. Bahkan mampu memberikan hasil produksi per hektar yang lebih tinggi (Lubis, 1992). Bagi Indonesia, tanaman kelapa sawit memiliki arti penting bagi pembangunan perkebunan nasional. Selain mampu menciptkan kesempatan kerja yang mengarah pada kesejahteraan masyarakat, juga sebagai sumber perolehan devisa negara. Indonesia merupakan salah satu produsen utama minyak sawit (Dirjen Perkebunan, 1987).

Di Propinsi Bengkulu, untuk perkebunan rakyat (PR) mempunyai luas lahan sebesar 24.529 ha dengan produksi kelapa sawit sebanyak 37.693 ton. Dan untuk perkebunan besar negara (PBN) mempunyai luas lahan 4.345 ha dengan produksi kelapa sawit 1.754 ton. Sedangkan untuk perkebunan besar swasta (PBS) mempunyai luas lahan 35.739 ha dengan produksi kelapa sawit sebanyak 58.335 ton. Dengan jumlah pabrik sebanyak 7 , kapasitas 
produksi pengolahan kelapa sawit di Propinsi Bengkulu mencapai 230 ton TBS/jam. Propinsi Bengkulu termasuk dalam 10 propinsi di Indonesia dengan kapasitas produksi pengolahan kelapa sawit yang tertinggi (Fauzi et al., 2002). Menurut Lubis (1996) dalam Setiawan (1998), untuk dapat mengoperasikan pabrik pengolahan CPO dengan kapasitas 30 ton/jam secara terusmenerus diperlukan lahan seluas 5.000 ha. Dengan luas lahan kebun kelapa sawit yang dimiliki oleh PT Bio Nusantara Teknologi saat ini yaitu 4.091,41 ha, perusahaan masih mengalami kesulitan dalam memenuhi kebutuhan pabrik sehingga untuk memenuhi kebutuhan pabrik, saat ini PT Bio Nusantara Teknologi menerima pasokan dari kebun luar yang jaraknya relatif jauh dari perusahaan dan dengan mutu TBS yang tidak dapat dikontrol dengan baik sehingga akan mempengaruhi hasil akhir yaitu mutu minyak sawit mentah dan inti sawit sebagai hasil sampingan, untuk menanggulangi penurunan mutu hasil akhir, perusahaan dapat mencukupi kebutuhan pabrik 30 ton/jam tersebut dengan melakukan penanaman baru kelapa sawit di kebun sendiri seluas 1000 ha yang didukung dengan luas pencadangan lahan yang tersedia seluas $1.102,59$ ha.

Mengingat dana investasi untuk penanaman baru per hektar areal kebun kelapa sawit relatif besar maka diperlukan analisis studi kelayakan proyek. Sehingga perusahaan dapat mengambil keputusan apakah proyek tersebut layak untuk dilaksanakan atau tidak layak untuk dilaksanakan. Penelitian ini bertujuan untuk 1) menganalisis aspek pemasaran TBS di Provinsi Bengkulu yang berhubungan dengan masalah permintaan dan penawaran perusahaan terhadap TBS, sehingga membuka peluang prospek pemasaran, 2) menganalisis kelayakan aspek teknis perluasan areal kebun kelapa sawit seluas 1.000 hektar pada PT Bio Nusantara Teknologi. Dan 3) menganalisis kelayakan aspek finansial perluasan areal kebun kelapa sawit seluas 1.000 hektar pada PT Bio Nusantara Teknologi. 


\section{Model Pendekatan}

Penelitian ini menggunakan model pendekatan secara diagramatis sebagai berikut :

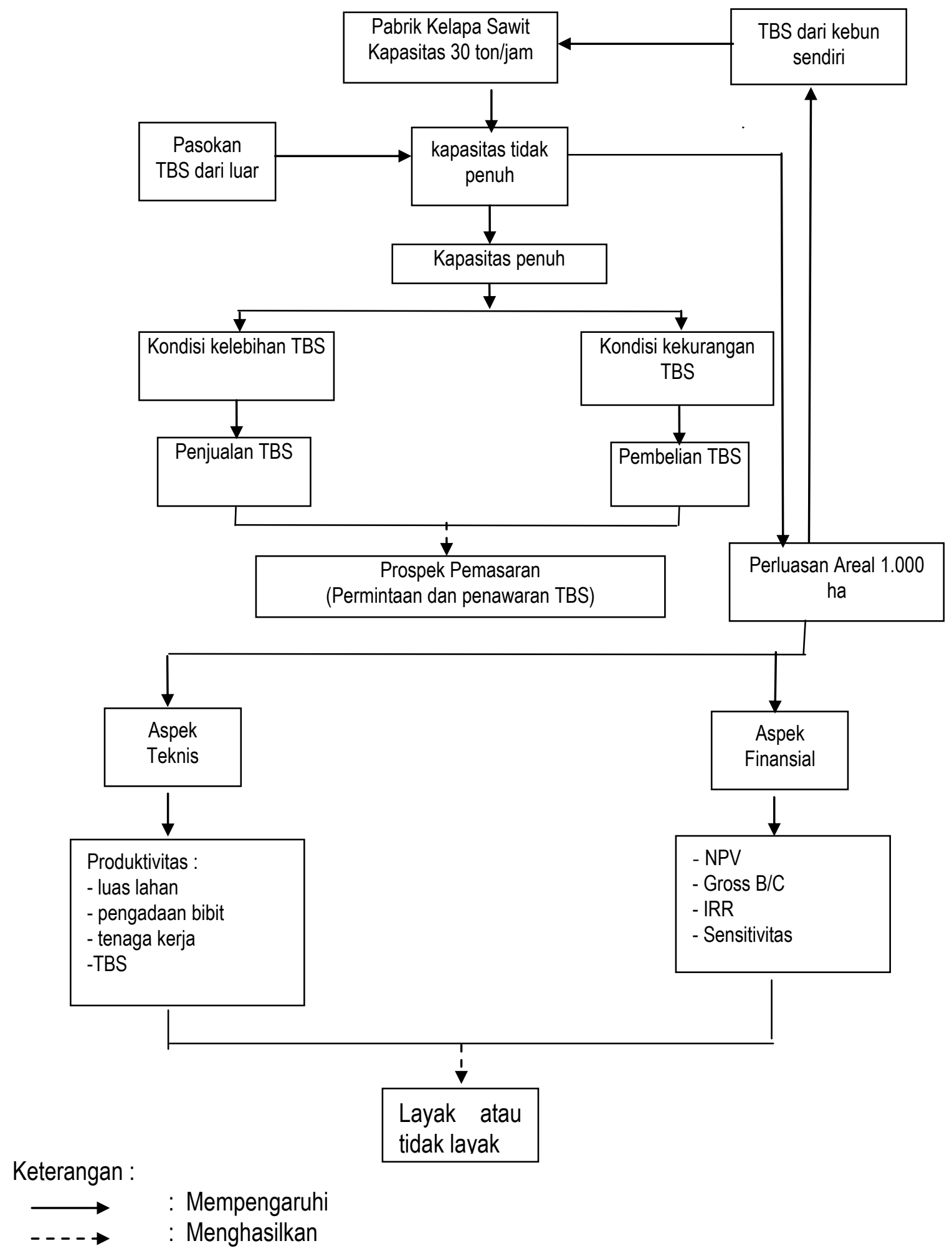




\section{Batasan-Batasan}

1. Responden adalah PT Bio Nusantara Teknologi di Kecamatan Pondok Kelapa Kabupaten Bengkulu Utara Provinsi Bengkulu.

2. Proses produksi yang dilakukan adalah pengolahan kelapa sawit menjadi minyak sawit, dengan kapasitas produksi 30 ton/jam.

3. Tandan Buah Segar (TBS) adalah tandan buah segar kelapa sawit yang dipasok dari luar dan hasil panen dari kebun PT Bio Nusantara Teknologi serta diserahkan pada hari yang sama kepada pabrik, selambat-lambatnya jam 24.00 waktu setempat.

4. TBS dari kebun sendiri adalah jumlah TBS yang dihasilkan dari kebun kelapa sawit milik PT Bio Nusantara Teknologi $(\mathrm{kg})$

5. Pasokan TBS dari luar merupakan banyaknya TBS yang dipasok dari luar untuk memenuhi kapasitas pabrik 30 ton/jam (kg).

6. Kapasitas tidak penuh adalah suatu kondisi dimana tidak terpenuhinya kapasitas pabrik yaitu 30 ton/jam.

7. Kapasitas penuh adalah suatu kondisi dimana terpenuhinya kapasitas pabrik 30 ton/jam.

8. Penjualan TBS adalah banyaknya TBS yang dijual oleh PT Bio Nusantara Teknologi jika tercapai kondisi full capacity sehingga memiliki kelebihan TBS (Rp/kg).

9. Pembelian TBS adalah banyaknya TBS yang dibeli oleh PT Bio Nusantara Teknologi jika mengalami kondisi non full capacity sehingga membutuhkan pasokan TBS dari luar $(\mathrm{Rp} / \mathrm{kg})$.

10. Prospek pemasaran TBS adalah peluang pemasaran TBS sehubungan dengan tingkat penawaran dan permintaan TBS oleh perusahaan-perusahaan di Provinsi Bengkulu.

11. Analisis studi kelayakan ini dilakukan pada proyek perluasan areal kebun kelapa sawit seluas 1.000 hektar.

12. Biaya produksi adalah total biaya yang dikeluarkan untuk memproduksi TBS yang terdiri dari biaya tetap dan biaya variabel (Rp/tahun).

13. Biaya tetap adalah biaya yang tidak habis dalam satu kali proses produksi,meliputi biaya saprodi dan biaya tenaga kerja (Rp/tahun). 
14. Biaya variabel adalah biaya produksi minyak sawit yang habis dalam satu kali proses produksi, meliputi biaya bibit, biaya benih LCC, biaya pupuk dan biaya obat-obatan (Rp/tahun).

15. Harga dan biaya-biaya yang dihitung adalah harga dan biaya-biaya yang terjadi pada tahun 2004

16. Harga jual adalah harga yang berlaku pada saat responden menjual TBS (Rp/kg).

17. Penerimaan perusahaan adalah harga jual produk dikalikan dengan jumlah produk yang terjual (Rp/tahun).

18. Keuntungan perusahaan adalah selisih antara peneriman dengan biaya total (Rp/tahun).

19. Produktivitas yang dianalisis dalam penelitian ini terdiri dari produktivitas TBS, luas lahan, pengadaan bibit dan tenaga kerja.

20. Gross B/C adalah alat yang digunakan untuk mengukur perbandingan antara keuntungan dengan biaya total produksi yang dikeluarkan PT Bio Nusantara Teknologi yang dipresentvaluekan.

21. NPV adalah salah satu alat ukur tingkat kelayakan yang merupakan selisih antara keuntungan (benefit) dengan pengeluaran (cost) PT Bio Nusantara Teknologi yang telah dipresentvaluekan (Rp).

22. IRR merupakan tingkat bunga yang menggambarkan besarnya NPV usaha produksi minyak sawit sama dengan nol (\%).

23. Analisis sensitivitas adalah analisis untuk melihat seberapa peka tingkat kelayakan akibat terjadi perubahan elemen-elemen atau komponen-komponen biaya dan penerimaan.

24. Kelayakan jangka pendek adalah perhitungan keuntungan dalam waktu satu tahun yang didapatkan oleh produsen pada rata-rata satu tahun kegiatan usaha.

25. Kelayakan finansial adalah alat ukur keberhasilan suatu usaha dilihat dari perhitungan Gross B/C, NPV, dan IRR serta analisis sensitivitas.

26. Tingkat diskonto atau discount rate sebesar $18 \%$ per tahun, yang dikeluarkan oleh PT Bank Mandiri Propinsi Bengkulu

Kelayakan Perluasan Areal Kebun Kelapa Sawit 1000 hektar (Penanaman Baru) PT. Bio Nusantara......( Gita M) 101 


\section{METODOLOGI PENELITIAN}

Penelitian ini dilaksanakan di PT Bio Nusantara Teknologi dimana pemilihan lokasi dilakukan secara sengaja (purposive) dengan pertimbangan PT Bio Nusantara Teknologi merupakan perusahaan pengolah kelapa sawit yang menerima bahan baku tandan buah segar (TBS) dari luar kebun untuk mencukupi kapasitas pabrik. Karena produksi TBS yang dihasilkan tidak dapat mencukupi kapasitas pabrik 30 ton/jam. Penelitian dilakukan pada bulan Juni sampai dengan bulan Agustus 2005. Metode penelitian yang digunakan adalah metode kasus, dimana PT Bio Nusantara Teknologi merupakan satuan kasus. Pemilihan PT Bio Nusantara Teknologi berdasarkan pertimbangan karena perusahaan ini adalah perusahaan yang mempunyai kapasitas tertinggi dalam memproduksi minyak sawit di Propinsi Bengkulu tapi produksi TBS yang dihasilkan tidak dapat mencukupi kebutuhan kapasitas pabrik sehingga masih memerlukan pasokan TBS dari kebun luar. Data yang diperoleh akan diolah secara matematis, disajikan secara tabulasi dan dijelaskan secara deskriptif. Untuk menjawab tujuan pertama, digunakan rumus sebagai berikut :

$$
\begin{aligned}
& Q_{D}=a+\beta \cdot n \\
& Q_{s}=a+\beta \cdot n
\end{aligned}
$$

Dimana :

$$
\begin{array}{ll}
\text { QD } & \text { : Tingkat permintaan TBS }(\mathrm{kg}) \\
\mathrm{QS} & \text { : Tingkat penawaran TBS }(\mathrm{kg}) \\
\mathrm{n} & : \text { Tahun }
\end{array}
$$

Pada tujuan pertama ini, akan dianalisis trend perkembangan permintaan dan penawaran TBS di tingkat Propinsi Bengkulu dari tahun ke tahun dengan memperhatikan trend perkembangan produksi TBS, harga TBS dan harga CPO yang terjadi di Provinsi Bengkulu. Data yang digunakan merupakan data time series dari tahun 1984 sampai dengan tahun 2004

Untuk megetahui tujuan kedua, akan dihitung luas lahan dan jumlah TBS yang diperlukan agar mencapai full capacity yaitu 30 ton/jam, menganalisis sistem rotasi penanaman kelapa sawit dan pergiliran masa panen kelapa sawit, menghitung jumlah tenaga kerja yang diperlukan untuk pelaksanaan proyek perluasan areal kebun kelapa sawit seluas 1.000 hektar. Untuk menjawab tujuan ketiga, rumus-rumus (Kadariah, 1998) yang digunakan adalah sebagai berikut : 
1. Untuk menghitung Gross $B / C$ :

Gross B/C $=\frac{B t \frac{1}{(1+i)^{t}}}{C t \frac{1}{(1+i)^{t}}}$

Dimana :

$\mathrm{Bt}=$ Benefit pada tahun ke-t

$\mathrm{Ct}=$ Cost pada tahun ke-t

$\mathrm{i}$ = Tingkat suku bunga

$\mathrm{t} \quad=$ Tahun $1,2,3, \ldots$

Jika :

$\mathrm{B} / \mathrm{C}>1 \ldots \ldots$. Untung

$\mathrm{B} / \mathrm{C}=1 \ldots \ldots .$. Impas

$\mathrm{B} / \mathrm{C}<1 \ldots \ldots$. Rugi

2. Untuk menghitung NPV :

$\mathrm{NPV}=\Sigma \frac{B t \quad C t}{(1+i)^{t}}$

Dengan kriteria :

NPV $>0$, Maka usaha layak

NPV $<0$, Maka usaha tidak layak

3. Untuk menghitung IRR :

$\mathrm{IRR}=i_{1}+\frac{N P V_{1}}{N P V_{1}-N P V_{2}}\left(i_{2}-i_{1}\right)$

Dimana :

$N P V_{1}=$ Nilai NPV yang positif $(R p)$

$N P V_{2}=$ Nilai NPV yang negatif $(R p)$

$\mathrm{i}_{1} \quad=$ discount rate pada NPV yang positif $(\%)$

$\mathrm{i}_{2}=$ discount rate pada NVP yang negatif (\%) 


\section{HASIL DAN PEMBAHASAN}

\section{Aspek Pemasaran TBS di Provinsi Bengkulu}

Dalam penelitian ini, telah dianalisis bagaimana trend yang berhubungan dengan aspek pemasaran TBS di Provinsi Bengkulu dengan melihat faktor-faktor yang berhubungan. Perkembangan produksi TBS di Provinsi Bengkulu, telah digambarkan dalam bentuk kurva. Kurva pertama merupakan trend perkembangan produksi TBS di Provinsi Bengkulu dan kurva kedua adalah trend perkembangan harga TBS dan harga CPO yang terjadi di Provinsi Bengkulu. Data yang digunakan adalah data time series, dari tahun 1984 sampai dengan tahun 2004 Untuk lebih jelasnya dapat dilihat pada Lampiran 2.

Produksi TBS mengalami peningkatan dari tahun ke tahun. Dari tahun 1984 sampai tahun 1990, peningkatan produksi TBS tidak terlalu tinggi, tetapi sejak tahun 1991 mengalami peningkatan yang cukup tinggi. Hal ini dikarenakan bertambahnya luas areal tanaman kelapa sawit dan bertambahnya umur tanaman kelapa sawit menjadi tanaman menghasilkan (TM) yang produktif lagi.Harga TBS di Provinsi Bengkulu dari tahun 1984 sampai dengan tahun 2001 mengalami peningkatan, walaupun tidak terlalu tinggi. Tetapi pada tahun 2002 dan tahun 2004 mengalami penurunan yang cukup drastis, hal ini dikarenakan tidak stabilnya situasi perekonomian Indonesia dan naik turunnya mata uang rupiah terhadap kurs dollar. Hal ini juga terjadi pada harga CPO, yang mengalami penurunan yang cukup drastis pada tahun 2002 dan tahun 2004.

\section{Aspek Teknis Perluasan Areal Kebun Kelapa Sawit 1000 Hektar di PT Bio Nusantara Teknologi}

Analisa secara teknis berhubungan dengan input proyek dan output proyek berupa barangbarang nyata dan jasa-jasa. Aspek teknis berpengaruh sangat besar terhadap kelancaran jalannya usaha, terutama kelancaran proses produksi

\section{Pengelolaan TB dan TBM Kelapa Sawit}

Tanaman baru (TB) pada perkebunan kelapa sawit terdiri dari land crearing atau pembukaan lahan, pembuatan jalan dan parit jalan, persiapan tanam/LCC dan penanaman bibit kelapa sawit. Land crearing untuk kebun kelapa sawit di PT Bio Nusantara Teknologi dilakukan secara mekanis, dengan menggunakan alat berat bulldozer. 
Dalam proyek ini akan dibuat 2 jalan yaitu jalan utama (main road) dan jalan produksi (collection road). Jalan utama lebarnya kurang lebih $8 \mathrm{~m}$ dan jalan produksi lebarnya kurang lebih $6 \mathrm{~m}$. Pembuatan parit bertujuan untuk mengalirkan air-air yang mengganggu tanaman selama dalam proses pertumbuhan. Kegiatan selanjutnya adalah adalah penanaman LCC (Leguminose Cover (rop) atau tanaman penutup tanah

Kegiatan terakhir adalah penanaman kelapa sawit. Bibit yang ditanam adalah bibit marihat yang berumur 12 bulan. Jarak tanam yang digunakan adalah $9 \mathrm{~m} \times 7,8 \mathrm{~m}$, dengan ukuran lubang $60 \mathrm{~cm} \times 60 \mathrm{~cm} \times 60 \mathrm{~cm}$.Semua kegiatan setelah penanaman kelapa sawit sebelum tanaman tersebut menghasilkan disebut TBM. Kegiatan pada TBM merupakan kegiatan pemeliharaan yang terdiri dari menyiang dan merumput, menunas dan pemupukan.

\section{Pemeliharaan TM Kelapa Sawit}

Pemeliharaan tanaman merupakan salah satu tindakan yang sangat penting dan menentukan masa produktif tanaman. Pemeliharaan tanaman menghasilkan (TM) kelapa sawit meliputi penyulaman, pemberantasan gulma, pemangkasan dan pemupukan.

\section{Sistem Panen TBS di PT Bio Nusantara Teknologi}

Kebun kelapa sawit di PT Bio Nusantara Teknologi menggunakan sistem panen ancak tetap. Artinya pada system ini, pemanen diberikan ancak dengan luas tertentu dan tidak berpindah-pindah. Hal tersebut menjamin diperolehnya TBS dengan pematangan yang optimal. Tiap kelompok panen terdiri dari 3-4 orang dengan luas areal kurang lebih 6-7,5 hektar. TBS yang sudah dipanen, dibawa ke tempat pengumpulan hasil (TPH) untuk ditimbang. Harga yang ditetapkan untuk $1 \mathrm{~kg}$ TBS adalah Rp 31/kg TBS.

\section{Produktivitas Tenaga Kerja}

Tenaga kerja yang digunakan dalam proyek perluasan areal kebun kelapa sawit seluas 1.000 hektar ini, terdiri dari tenaga kerja tetap dan tenaga kerja harian. Perbedaan antara kdua tenaga kerja ini adalah terletak pada upah yang diberikan dan tugas dari masing-masing tenaga kerja.Tenaga kerja tetap terdiri dari 1 asisten kepala, 2 asisten afdeling, 5 asisten lapangan, 1 mandor I, 4 mandor pemeliharaan, 2 krani infras, 1 administrasi tata usaha, dan 4 mandor panen. Tenaga kerja tetap ini mempunyai kebutuhan gaji yang berbeda sesuai dengan jabatan tugas mereka.

Tenaga kerja harian merupakan tenaga kerja yang upahnya dihitung harian sesuai dengan berapa hari waktu kerja mereka. Upah harian yang diberikan oleh perusahaan untuk tenaga kerja 
harian ini yaitu sebesar Rp. 17.200,00. Adapun penggunaan dari tenaga kerja harian ini adalah untuk pembukaan lahan, pembuatan jalan dan teras, persiapan tanam LCC, penanaman, pemeliharaan, menyiang dan merumput, pemupukan dan persiapan panen

\section{Produksi TBS}

PT Bio Nusantara Teknologi merupakan salah satu pabrik pengolahan kelapa sawit yang mempunyai kapasaitas tertinggi yaitu 30 ton/jam. Tapi produksi TBS yang dihasilkan dari kebun sendiri tidak dapat mencukupi kapasitas pabrik sehingga memerlukan pasokan TBS dari luar. Untuk mencapai full capacity, secara teori PT Bio Nusantara Teknologi memerlukan kurang lebih 420 ton TBS per harinya. Apalagi saat ini PT Bio menetapkan 2 shift kerja per harinya, dimana masing-masing shift kerja mempunyai 7 jam waktu kerja. Tapi pada kenyataannya, PT Bio Nusantara Teknologi sering tidak mencapai kapasitas pabrik. Berapapun jumlah TBS yang masuk ke dalam pabrik akan langsung diolah, hal ini untuk menjaga kesegaran buah TBS dan mutu CPO yang dihasilkan.

\section{Aspek Finansial}

\section{Permodalan Proyek Perluasan Areal Kebun Kelapa Sawit 1.000 Hektar}

Sumber modal terdiri dari sumber internal (internal sources) dan sumber eksternal (external sources). Modal yang berasal dari sumber internal adalah modal yang dibentuk atau dihasilkan sendiri di dalam perusahaan. Modal yang berasal dari sumber eksternal adalah modal yang berasal dari luar perusahaan, yaitu dari kreditur yang merupakan hutang. Berdasarkan analisis investasi, modal yang diperlukan untuk rencana perluasan areal kebun kelapa sawit 1.000 hektar pada PT Bio Nusantara Teknologi adalah Rp. 9.703.500.000,00. Investasi sebesar ini tidak sepenuhnya dipenuhi dari modal sendiri. Oleh karena itu perusahaan memutuskan untuk meminjam dari PT Bank Mandiri berupa kredit investasi jangka panjang. Perusahaan memutuskan untuk meminjam sebesar $90 \%$ dari modal investasi, sehingga modal pinjaman menjadi Rp. 8.733.150.000,00 dan $10 \%$ dari modal investasi berasal dari kas keuangan PT Bio Nusantara Teknologi, yaitu sebesar Rp. 970.350.000,00.

Masa pengembalian pinjaman selama 10 tahun dengan grace period selama 4 tahun. Artinya perusahaan harus mulai membayar angsurannya pada tahun ke-empat setelah proyek dijalankan. Pengembalian pokok pinjaman dilakukan dengan cara berangsur-angsur setiap tahunnya, yaitu pengembalian dilakukan mulai tahun ke-empat sampai tahun ke-sepuluh dengan 
jumlah pokok pengembalian yang sama. Bunga yang dibayarkan sebesar $17 \%$ dari sisa saldo yang belum dilunasi setiap tahunnya.

\section{Biaya Investasi}

Biaya investasi perluasan kebun kelapa sawit 1.000 hektar terdiri dari biaya pembersihan lahan, biaya pembuatan jalan utama, biaya pembuatan jalan produksi, biaya pembuatan teras, biaya pembuatan jembatan, biaya pembuatan gorong-gorong, biaya pembuatan jalan angkong, dan biaya pembuatan pasar pikul. Masa investasi hanya dikeluarkan pada tahun pertama, yang diasumsikan untuk investasi jangka panjang. Biaya investasi yang dikeluarkan pada tahun pertama ini, yaitu sebesar Rp. Rp. 4.659.963.160,00. Untuk lebih jelasnya mengenai biaya investasi dapat dilihat pada Tabel 2

Tabel 1. Perkiraan Biaya Investasi (Rp/1000 Ha)

\begin{tabular}{clr}
\hline No. & \multicolumn{1}{c}{ Komponen Biaya } & Biaya \\
\hline 1. & Pembersihan Lahan & $1.188 .727 .160,00$ \\
2. & Pembuatan Jalan Utama & $1.041 .250 .000,00$ \\
3. & Pembuatan Jalan Produksi & $1.388 .986 .000,00$ \\
4. & Pembuatan Teras & $500.000 .000,00$ \\
5. & Pembuatan Jembatan & $275.000 .000,00$ \\
6. & Pembuatan Gorong2 & $125.000 .000,00$ \\
7. & Pembuatan Jalan Angkong & $21.000 .000,00$ \\
8. & Pembuatan Pasar Pikul & $120.000 .000,00$ \\
\hline & Jumlah & $4.659 .963 .160,00$ \\
\hline
\end{tabular}

\section{Biaya Operasional}

Biaya operasional dihitung mulai dari tahun pertama. Biaya operasional terdiri dari biaya sarana dan prasarana produksi, biaya pemeliharaan dan biaya tenaga kerja. Biaya sarana dan prasarana produksi adalah biaya yang dikeluarkan untuk membeli berbagai sarana dan prasarana yang diperlukan dalam proyek perluasan areal kebun kelapa sawit

\section{a. Bibit Kelapa Sawit}

Bibit kelapa sawit merupakan bibit yang telah berumur 12 bulan yang sebelumnya telah dikembangkan di lokasi pembibitan. Biaya bibit kelapa sawit ini dikeluarkan pada tahun pertama sebesar Rp. 670.000.000,00. per hektar. Besarnya biaya bibit dikarenakan bibit yang digunakan adalah bibit unggul. Bibit kelapa sawit yang diperlukan untuk satu hektar berjumlah 141 pohon. Sedangkan jumlah bibit yang ditanam pada lahan satu hektar adalah 134 pohon dengan jarak tanam 9 meter $\times 7,8$ meter. Kelebihan $5 \%$ dari bibit kelapa sawit ini dimaksudkan sebagai 
cadangan bibit apabila ada bibit yang pertumbuhannya tidak normal, jadi bisa segera digantikan dengan bibit yang normal.

\section{b. Benih LCC}

Adapun jumlah biaya yang dikeluarkan untuk biaya pembelian benih LCC adalah sebesar Rp 385.000,00. per hektar. LCC dimaksudkan untuk mencegah erosi tanah, memperbaiki penyediaan air tanah,, mengikat $\mathrm{N}$ di udara, dan menjaga kelembaban tanah. LCC ditanam sebelum penanaman bibit kelapa sawit

\section{c. Pupuk Kelapa Sawit}

Harga satuan untuk pembelian pupuk Rock phospat adalah Rp $1.200,00 / \mathrm{kg}$, pupuk urea Rp. $1.100,00 / \mathrm{kg}$, dan pupuk KCL $1.800,00 / \mathrm{kg}$. Untuk tahun pertama sampai dengan tahun terakhir umur tanaman, dosis pupuk yang diberkan semakin meningkat

\section{d. Obat-obatan}

Obat-obatan yang digunakan adalah Round Up untuk mematikan ilalang yang tumbuh disekitar tanaman kelapa sawit. Biaya obat-obatan dikeluarkan pada tiga tahun pertama, dengan takaran obat yang semakin rendah dari tahun ke tahun. Harga satuan untuk pembelian Round Up adalah $\operatorname{Rp} 29.000 /$ iter.

\section{e. Prasarana Produksi}

Prasarana produksi yang digunakan adalah Sprayer, cangkul, ember plastik, takaran pupuk, dodos dan kampak. Alat-alat tersebut digunakan sesuai dengan fungsi dan waktu yang sesuai.

Tabel 2. Perkiraan Biaya Operasional (Rp/1000 Ha)

\begin{tabular}{clc}
\hline No. & \multicolumn{1}{c}{ Komponen Biaya } & Biaya \\
\hline 1. & Biaya Bibit & $670.000 .000,00$ \\
2. & Biaya Benih LCC & $385.000 .000,00$ \\
3. & Biaya Pupuk LCC & $12.000 .000,00$ \\
4. & Biaya Pupuk Kelapa Sawit & $524.800 .000,00$ \\
5. & Biaya Obat-obatan & $139.200 .000,00$ \\
6. & Biaya Sarana & $10.655 .000,00$ \\
7. & Biaya Persiapan Tanam LCC & $309.600 .000,00$ \\
8. & Biaya Penanaman & $301.000 .000,00$ \\
9. & Biaya Pemeliharaan Prasarana & $1.191 .400 .000,00$ \\
10. & Biaya Menyiang dan Merumput & $189.200 .000,00$ \\
11. & Biaya Pemupukan & $103.200 .000,00$ \\
12. & Biaya Persiapan Panen & $5.332 .000,00$ \\
13. & Gaji Organisasi Proyek & $362.400 .000,00$ \\
\hline & $\quad$ Jumlah & $4.203 .787 .000,00$ \\
\hline
\end{tabular}




\section{Analisis Finansial}

Manfaat pada analisis finansial perluasan areal kebun kelapa sawit di PT Bio Nusantara Teknologi merupakan penerimaan yang diperoleh dari hasil kali jumlah produksi dan harga TBS yang berlaku Harga TBS yang dipakai dalam perhitungan penelitian ini adalah harga TBS ratarata pada tahun 2004 yang informasinya didapatkan dari Dinas Perkebunan Provinsi Bengkulu.

Penerimaan perusahaan dari perkebunan kelapa sawit seluas 1000 hektar yang dianalisis dalam penelitian ini didasarkan atas potensi produksi berdasarkan produksi optimum PT Bio Nusantara Teknologi. Penerimaan terendah diperoleh pada tahun pertama menghasilkan, yaitu pada tahun ke-tiga. Pada tahun ke-sebelas penerimaan yang diperoleh mulai konstan dan pada tahun ke-dua puluh satu, penerimaan turun menjadi sebesar Rp. 17.494.837.500,00. sampai akhir umur efektif ekonomisPenerimaan perusahaan dari perkebunan kelapa sawit seluas 1000 hektar yang dianalisis dalam penelitian ini didasarkan atas potensi produksi berdasarkan produksi optimum PT Bio Nusantara Teknologi. Penerimaan terendah diperoleh pada tahun pertama menghasilkan, yaitu pada tahun ke-tiga. Pada tahun ke-sebelas penerimaan yang diperoleh mulai konstan dan pada tahun ke-dua puluh satu, penerimaan turun menjadi sebesar Rp. 17.494.837.500,00. sampai akhir umur efektif ekonomis

\section{a. Gross $B / C$}

Gross $B / C$ adalah ukuran kelayakan usaha yang merupakan perbandingan antara penerimaan dan biaya yang telah dipresentvaluekan Discount factor adalah suatu bilangan yang dapat dipakai untuk mengalikan suatu jumlah di waktu yang akan datang supaya menjadi nilai sekarang. Tingkat bunga yang digunakan disesuaikan dengan rata-rata bunga yang berlaku pada saat penelitian yaitu sebesar $18 \%$. Dari hasil pengolahan data didapatkan bahwa nilai gross $B / C$ proyek perluasan areal kebun kelapa sawit seluas 1000 hektar adalah sebesar 1,65 yang berarti bahwa setiap Rp 1.000,00 dari biaya yang dikeluarkan akan memperoleh benefit sebesar Rp 1.650,00. Ini berarti proyek perluasan areal kebun kelapa sawit seluas 1000 hektar layak untuk dilaksanakan.

\section{b. Net Present Value (NPV)}

Net Present Value (NPV) merupakan selisih antara benefit (penerimaan) sekarang dengan cost (biaya) sekarang. Tingkat diskonto yang digunakan adalah 18\%. Besarnya NPV adalah Rp. 18.574.764.528 yang berarti bahwa keuntungan bersih sekarang yang diterima oleh PT Bio 
Nusantara Teknologi yang melakukan proyek perluasan areal kebun kelapa sawit seluas 1000 hektar adalah sebesar Rp 18. 574.764.528. Hal ini berarti proyek layak untuk dilaksanakan.

\section{c. Internal Rate of Return (IRR)}

Internal Rate of Return (IRR) adalah suatu kriteria atau alat ukur kelayakan usaha untuk mengetahui nilai tingkat bunga (discount rate) pada usaha memperoleh NPV sama dengan nol yang berarti IRR lebih besar dari tingkat suku bunga yang berlaku sekarang, maka usaha tersebut layak diusahakan dan jika IRR lebih kecil dari tingkat suku bunga yang berlaku sekarang, maka usaha tersebut tidak layak. Pada penelitian ini diperoleh nilai IRR sebesar 19,06\%, nilai ini lebih besar daripada tingkat suku bunga yang berlaku pada saat sekarang yaitu sebesar $18 \%$. Hal ini berati proyek perluasan areal kebun kelapa sawit seluas 1000 hektar layak untuk diusahakan.

\section{Analisis Sensitivitas}

Hasil perhitungan menunjukkan bahwa discount rate 18\% dengan menurunkan harga TBS sebesar $5 \%$ dan biaya pemeliharaan prasarana sebesar 10\% diperoleh bahwa proyek perluasan areal kebun kelapa sawit seluas 1000 hektar di PT Bio Nusantara Teknologi masih layak untuk dilaksanakan. Dapat dilihat dari nilai gross B/C yang diperoleh sebesar 6,24 dan NPV sebesar Rp 37.574.864.100 serta IRR 29,18\%.

\section{KESIMPULAN DAN SARAN}

\section{Kesimpulan}

Berdasarkan analisis, maka kesimpulan yang diperoleh adalah :

1. Dengan semakin meningkatnya kapasitas pabrik perusahaan-perusahaan pengolah kelapa sawit dan semakin banyaknya permintaan TBS dari perusahaan-perusahaan pengolah kelapa sawit di Provinsi Bengkulu telah membuka prospek pemasaran TBS yang cukup baik bagi para investor yang ingin menanamkan modalnya. Selain itu, semakin meningkatnya harga TBS dan harga CPO menjadi faktor pendukung bagi prospek pemasaran TBS di Provinsi Bengkulu.

2. Dari aspek teknis, usaha perluasan areal kebun kelapa sawit seluas 1.000 hektar tidak mengalami masalah untuk dilaksanakan. Hal ini dapat dilihat dari semakin matangnya persiapan teknik yang telah dipersiapkan untuk proyek ini.

3. Investasi perluasan areal kebun kelapa sawit seluas 1.000 hektar di PT Bio Nusantara Teknologi secara finansial layak untuk dilaksanakan, dengan diperolehnya Gross B/C 1,65, IRR19,06\% dan NPV sebesar Rp. 18.574.764.528. 
4. Berdasarkan analisis sensitivitas yang dilakukan, diketahui bahwa perluasan areal kebun kelapa sawit seluas 1.000 hektar di PT Bio Nusantara Teknologi sensitif terhadap perubahan harga TBS dan perubahan biaya pemeliharaan prasarana. Proyek tersebut layak untuk dilaksanakan pada kenaikan biaya pemeliharaan prasarana $10 \%$ per tahun dan harga TBS yang turun $5 \%$ per tahun, dengan Gross B/C 6,24 dan IRR 29,18\% serta NPV Rp 37.574.864.100

\section{Saran}

Adapun saran yang dapat diambil dari penelitian ini yaitu walaupun analisis proyek perluasan areal kebun kelapa sawit pada PT Bio Nusantara Teknologi secara finansial layak untuk dilaksanakan, lebih baik sebelum pelaksanaannya dianalisis juga aspek-aspek lainnya seperti aspek teknis, aspek manajerial dan administratif, aspek organisasi, aspek komersial, dan aspek ekonomi untuk memperkuat pertimbangan pelaksanaan proyek perluasan kelapa sawit pada PT Bio Nusantara Teknologi.

\section{DAFTAR PUSTAKA}

Dirjen Perkebunan Departemen Pertanian. 1987. "Pedoman Bercocok Tanam Kelapa Sawit" (Jakarta: Dirjen Perkebunan Departemen Pertanian).

Fauzi, Y. T.E Widyastuti,I. Satyawibawa \& R. Hartono. 2002. Seri Agribisnis Kelapa Sawit. 2002. Penebar Swadaya. Jakarta.

Kadariah. 1988. Evaluasi Proyek (Analisa Ekonomis). FE UI. Jakarta.

Lubis, Adlin U. 1992. Kelapa Sawit (Elaeis guneensis Jacq.) di Indonesia. Bandar Kuala: Pusat Penelitian Marihat. 